\title{
Parental Involvement in Young Children's Learning of Numeracy
}

\author{
Munirah Ghazali, Zainun Mustafa, \\ Rabiatul-Adawiah Ahmad Rashid and Fadzilah Amzah \\ Universiti Sains Malaysia, Malaysia \\ https://orcid.org/0000-0002-7197-350X \\ https://orcid.org/0000-0002-0797-724X \\ https://orcid.org/0000-0002-6689-9704 \\ https://orcid.org/0000-0001-7576-9840
}

\begin{abstract}
This study seeks to assess the Malaysian parental involvements in young children's numeracy learning. A questionnaire was administered to 327 parents of kindergarten-going children. The data then analysed descriptively using Statistical Package for the Social Sciences version-26. The present survey shows that the parents' knowledge, understanding, and attitude towards preschoolers' numeracy are high. Despite the positive findings, the parents' attitudes and experience in mathematics are moderate. The analysis found that parents need a relevant guide to support their children learning at home using effective instructional strategies. This research's data formed an initial insight to support a comprehensive follow-up study in parental involvement in young children's numeracy learning. Based on these findings, it is pertinent to investigate the underlying factors and constraints behind these results. The study will benefit researchers, parents, children, school, as well as the entire community in general. Conclusion and future recommendation are further discussed.
\end{abstract}

Keywords: numeracy; pre-school; parental involvement; parent participation; questionnaire

\section{Introduction}

Numeracy refers 'to the ability to do basic arithmetic operations, understanding the simple mathematical ideas and applying the knowledge and skills in mathematics in daily life' (Curriculum Development Centre [CDC], 2010). As much as the numeracy is concerned in the national education system, the children early numeracy is fostered by the quality of home-learning (Purpura et al., 2020; Soto-Calvo et al., 2020) and parental support at an early age (Lin et al., 2019; Visser, Juan \& Hannan, 2019). The importance of numeracy is fairly acknowledged, as it sets as profound for the understanding of much complex mathematic later on. A comparative study on Trends in International 
Mathematics and Science Study (TIMMS), particularly in mathematics found that the Malaysian students perform relatively lower than Singapore. Ng et al., (2012) further emphasized that even though both countries have similar educational structures such as centralized educational systems and schooling routine, parental involvement positively predicts both countries' mathematics achievement regardless of their performance. However, Ubale and Abdullah (2015) acclaimed that parental involvement in Malaysia is scarce even though the Malaysian Ministry of Education (MOE) encouraged parents to be an active partner with the school. Husen and Mansor (2018) even conclude that elementary mathematics children's performance depended on the reflection of their parents' attitudes and aspirations. Although it is accepted that children's later mathematical achievement is most directly affected by prior knowledge and experience in early numeracy, the research on examining the parental involvement in children's numeracy learning environment before formal schooling in Malaysia is insufficient.

The purpose of this study is to explore the parental involvement in the facilitation of their children's acquisition of numeracy and number concepts. Therefore, to fulfil the purpose of the study, some research questions are underlined;

i. What is the level of parents' knowledge about preschool mathematics?

ii. What is the level of parents' readiness to be involved in the mathematical activities at home?

iii. What is the level of parents' understanding of the importance of mathematics?

iv. What is the level of parents' experience in mathematics?

v. What is the level of parents' attitudes towards mathematics?

The data accumulated from this research provides baseline evidences of the current practice of parental involvement in young children's mathematical education in the Malaysian education landscape. The reference value from the analysis reveals misunderstandings that may represent obstacles to the ongoing numeracy-related program and serve a ground to propose a new intervention strategy related to parental involvement in early numeracy in Malaysia.

\section{Background of Study}

Early numeracy is crucial in a child's learning progression in mathematical skills and mathematical thinking. The awareness should be raised to ensure that the quality of early numeracy serves a firm ground for more advanced numerical cognitions. The importance of children's ability to master necessary numeracy skills is acknowledged in the Malaysian education system since 1996 (Harun et al., 2017). The preschool mathematic curriculum in Malaysia underwent several changes until the recent newly revised National Preschool Curriculum Standard (KSPK) was developed in 2010. According to Harun et al. (2017), early numeracy in the Malaysian preschools covers the topics that include pre-number numbers, basic number operation, the value of money, time, shape, and space.

Meanwhile, LINUS (Literacy and Numeracy Screening) is introduced as the national diagnostic assessment system since 2013 to monitor the students' 
numeracy ability from year one until year three. This assessment is tailored with a remedial program to decrease the young children's polarisation in an early numeracy ability (Wei \& Hutagalung, 2014). Despite this program positive remark (Peng, Leng \& Hutagalung, 2016), this standard tools-aided program was repealed in 2019. Singh et al. (2019) found out that the newly introduced syllabus (i.e Standard Based Curriculum for Secondary Schools and Standard Based Curriculum for Primary Schools) integrated with the mathematical thinking and enumeration in composite and multi-layered across all the topics, compared to the confined remedial program which specifically to cater a particular group of students in LINUS.

Henceforth, the government's remarkable approach in the new syllabus is also a part of the current notion to acknowledge the school initiatives to address and curb their respective issue (i.e., numeracy) at the individual level. The sound decision is aligned with the recent finding that shows the development of young children's numerical cognition is fluid, dynamic, and unique based on biological and cultural perspectives (Pantsar, 2019; Xu, Spelke \& Goddard, 2005).

\subsection{Children's ability in numeracy}

The numeracy is a composite proficiency of the mathematical thinking (DíezPalomar, 2019; Jain \& Rogers, 2019) and numerical skills (Mutaf-Yıldız et al., 2019; Susperreguy et al., 2020). Vacher (2014) claimed that from the psycholinguistic and ontological perspectives, numeracy is synonymous with "quantitative literacy" and "quantitative reasoning." It is widely accepted that numeracy is not segmented in one topic; it is somewhat stretched throughout the cross-topically in the early mathematical curriculum (Bennison, 2019; Goos et al., 2020). The study concerning numeracy in early childhood has been documented for more than 200 years (Cohen, 2001; Sharp, 2018) and proliferated in the broad corpus of study.

The importance of early numeracy experience as the foundation for mathematical learning in school is frequently reported. To demonstrate, the past studies found a significant predictive link between the verbal counting skills (Koponen, Aunola \& Nurmi, 2019), subitising (Hannula-Sormunen, Lehtinen \& Räsänen, 2015), basic arithmetics (Singer \& Strasser, 2017; Pardo, et al., 2020), and number concepts (Balt, Fritz \& Ehlert, 2020) in early years with later mathematics performance in school. Sobkow, Olszewska and Traczyk (2020) and Darriet, et al. (2020) claimed that the numerical competency could further predict preferences in real-life choices. However, the individual differences in numeracy are distinguished in an early age and persisted in later development.

\subsection{Parental Involvement Could Affect the Numeracy Learning of Children}

From the perspective of human development, the innate number sense is naturally developed since fetal (Bull, Davidson \& Nordmann, 2010) and infancy/toddler (Vandervert, 2017; Whitacre, Henning \& Atabas, 2017; Xu, Spelke \& Goddard, 2005). Ostensibly, studies in number sense or early numeracy tried to comprehend the physiological determinant (Wilkey \& Ansari, 2019), psychological determinant (Kesler et al., 2011), gene and heritability determinant (Tosto et al., 2014) in early numerosity. For instance, the nature of individual 
factors extensively studied include neurocognition (Raghubar \& Barnes, 2017), inhibition (Clayton \& Gilmore, 2015), attention (Brueggemann \& Gable 2018), motivation (Martin \& Lazendic, 2018), challenged learner (Silva et al., 2020) and gender (Brandlistuen \& et al., 2020; Toivainen et al., 2017).

Hence, despite the 'nature', the advancement and competency in numeracy are also determined by 'nurture' as well. The nurture or environmental factors denote as contributing factors in the development of early numeracy, such as home ecology (Napoli \& Purpura, 2018), socioeconomic status (Forgasz \& Leder, 2020), cultural variations (Ayonrinde et al., 2020) and pedagogical approach (i.e., Piper et al., 2018; Budgen \& West 2020). These studies consistently found that children's ability to perform numerical competency is attributed to early childhood homelearning environments as support to preschool education.

Parental involvement in supporting children's ability in numeracy is fairly appraised. Ubale and Abdullah (2015) analyse several definitions on parental involvement, concluded that "parental involvement can be a label as a parental contribution as well as taking part towards the learning goals' achievement of their children" (p.348). Thus, the parental involvement is diverged beyond home-basedteaching towards the various domain of parent-child interaction. The positive relationship between parent-child interactions in the numeracy activities include numerical content, attention focus, emotions, and social connection (Skwarchuk, Vandermaas-Peeler \& LeFevre, 2016; Vandermaas-Peeler, Westerberg \& Fleishman, 2019). Theoretically sound with Vygotsky's social development theory (Vygotsky, 1978), parental involvement in children's early numeracy is a form of social internalisation of knowledge (Edens \& Potter 2013). To put it simply, the parent-child interactions in numeracy are considered as one of the critical educational capitals and resources.

The parent-child interactions in numeracy are further framed into two; formal and informal (Cahoon, Cassidy, \& Simms, 2017). Formal activities refer to a wellstructured outline of teaching and learning guides with explicit instruction. The guides serve as the manual for the parents or educators outlined with particular objectives, plans of activities, and assessment meant for reflection. The stimulating formal activities include worksheet activity, drilling practice, oral memorisation, and technology-guided software or application (Aunio et al., 2016; BaccagliniFrank, Carotenuto \& Sinclair, 2020). In contrast, informal activities are the result of situational or incidental learning. The learning prompt at home may occur during a visit to the museum (Vandermaas-Peeler, Massey, \& Kendall, 2016), playing board or card games (Ramani \& Scalise 2020), money-talk when shopping (Barrera-Mora \& Reyes-Rodriguez, 2019), and measuring ingredients when cooking (Son \& Hur, 2020; Finn \& Vandermaas-Peeler, 2013). The endless possibilities to infuse numeracy learning at home means that the preschool period may be an especially important time to examine the effects parents can have in developing children's mathematical skills.

The pool of research evidence demonstrates that first-grade children's mathematics performance differs in different environments (Lore, Wang \& 
Buckley, 2016; Silinskas et al., 2020; Aunio et al., 2016). Weerasinghe (2017) identified parental attitudes, beliefs, expectations, values, educational aspirations, and academic standards as crucial attributes in children's perception of learning mathematics to understand the difference. Pritchard (as cited in Muir, 2012) concluded that there were links between parents' attitudes, perceptions, and beliefs about mathematics and children's attitudes and performance in mathematics. In a similar vein, Rogers, Bastandardisedrblett and Robinson (2018), measured the parent's perception by highlighting parental involvement in an early numeracy which is linked with children's primary numerical and/or mathematical performance (Mutaf-Yıldız et al., 2018). However, previous studies examining parents' beliefs on mathematics were somewhat inconclusive (Sonnenschein et al., 2012; Galindo \& Sonnenschein, 2015; Missall et al., 2015).

Several studies have shown that low-income parents thought that the children mathematics learning were more critical in pre-school than in the home environment (DeFlorio \& Beliakoff, 2015), presumably due to low socioeconomic and educational status, parents had lower confidence in their teaching abilities (Burns, 2020; Drummond \& Stipek, 2004; Cui, Zhang \& Leung, 2019). Furthermore, past cross-country studies found that parental involvement in early childhood education relied on their country economic status (i.e., Sobayi, 2018; Cheung \& Pomerantz, 2011; Nilsen et al., 2020) and parents past experiences (O'Toole \& de Abreu (2005).

Therefore, the preschool period may be an especially important time in examining the effects parental involvement can have towards the development of children's mathematical skills. This article was part of a bigger study that explored parents' knowledge in numeracy specifically through the following constructs; knowledge about preschool mathematics, readiness to be involved in preschool mathematics activities at home, understanding the importance of preschool mathematics, experience during respective parents' previous learning of mathematics and attitudes towards mathematics.

\section{Methodology}

This survey employed a quantitative method using a set of predefined questions formatted in systematised questionnaires (see Appendix 1). The questionnairebased survey was administered to the representative samples $(n=327)$ of parents residing in Peninsular Malaysia (Kedah, Kelantan, and Pulau Pinang) and East Malaysia (Sarawak). The sampling procedure was carried out through stratified purposive sampling. From the 327 questionnaires distributed, 307 of the questionnaires were returned. The final 307 questionnaires were further analysed to establish the understanding of parental involvement in terms of five constructs; 1) parents' knowledge about preschool mathematical practices and curriculum, 2) parents' readiness to involve in mathematical activities at home, 3) parents' understanding of the importance of mathematics, 4) experience in mathematics and 5) attitude towards numeracy and number concepts of four following components of numeracy. These components are comparison, classification, one to one correspondence and seriation concept. The number of items per construct and the constituents' Likert Scale point is summarised in Table 1. 
Table 1. The number of items for each construct and the Likert scale point.

\begin{tabular}{lcc}
\hline Constructs & $\begin{array}{c}\text { Number } \\
\text { of items }\end{array}$ & $\begin{array}{c}\text { Likert-scale } \\
\text { point }\end{array}$ \\
\hline $\begin{array}{l}\text { Knowledge about preschool mathematics practices and } \\
\text { curriculum }\end{array}$ & 11 & 5 \\
Readiness to involve in mathematical activities at home & 5 & 5 \\
Understand the importance of mathematics & 10 & 5 \\
Experience in mathematics & 5 & 3 \\
Attitudes towards mathematics & 8 & 5 \\
\hline
\end{tabular}

The concept of parental involvement in the early numeracy in this study was indexed via questionnaires. Thus, self-perspectives on parental involvement to facilitate the children's acquisition of numeracy was recorded using declarative rated-statement. The data was analysed descriptively. The frequency of the demographic profile was tabulated and all the response means were analysed descriptively.

\subsection{Instrumentation}

The instruments consisted of five aspects which specifically encompassed parental involvement in young children's learning of numeracy according to previously discussed construct. The questionnaire item was developed by the team of expert from our institution through a series of questionnaire development training. Even though the data were collected from multiracial community, the medium of instruction in classroom was in the Malay language as the national language or/and English, similar to the medium of instruction in the questionnaire. The procedure of participant and data confidentiality was adhered to the guidelines by Education Policy Planning and Research Division, Ministry of Education Malaysia [EPRD], 2021). The details of instruments development, piloting, validity/reliabity testing and research ethics were reported comprehensively in the monograph in Ghazali et al. (2017).

\section{Findings of Study}

The parental involvement in the facilitation of their children's acquisition of numeracy and number concepts was obtained from the quantitative data. The frequency of all the response means were analysed descriptively.

\subsection{Parents' Knowledge about Preschool Mathematics}

As shown in Table 2-on parents' perceived knowledge about preschool mathematics, this research focused on the 11 items according to the topics in the early mathematics curriculum. Based on Table 3, most respondents answered "Capable." Based on SPSS data, it appeared that item 1 of writing numbers showed the highest means value of $\mathrm{M}=4.65$ ( $\mathrm{SD}=0.73$ ). Item 11 displayed the lowest mean value of $\mathrm{M}=4.30$ ( $\mathrm{SD}=0.93$ ). In this construct, more than $60 \%$ of parents answered all the items on the scale of "very capable". In contrast, only for items 10 and 11 , the percentage that was less than $60 \%$. 
Table 2. Distribution of mean and standard deviation of parents' knowledge about preschool mathematics

\begin{tabular}{|c|c|c|c|}
\hline No. & Items & Mean (M) & $\begin{array}{c}\text { Standard } \\
\text { Deviation (SD) }\end{array}$ \\
\hline 1. & Writing numbers & 4.65 & 0.73 \\
\hline 2. & $\begin{array}{l}\text { Comparing objects based on particular } \\
\text { characteristics }\end{array}$ & 4.63 & 0.69 \\
\hline 3. & Comparing numbers & 4.58 & 0.75 \\
\hline 4. & $\begin{array}{l}\text { Classification of objects based on } \\
\text { particular characteristics }\end{array}$ & 4.58 & 0.73 \\
\hline 5. & $\begin{array}{l}\text { Arranging object based on particular } \\
\text { criteria }\end{array}$ & 4.59 & 0.74 \\
\hline 6. & Matching identical pair object & 4.61 & 0.72 \\
\hline 7. & Matching non-identical pair object & 4.56 & 0.74 \\
\hline 8. & $\begin{array}{l}\text { Matching object with equal or different } \\
\text { quantity }\end{array}$ & 4.55 & 0.75 \\
\hline 9. & Number concepts & 4.53 & 0.78 \\
\hline 10. & $\begin{array}{l}\text { Exercises/Activities with learning } \\
\text { materials/games }\end{array}$ & 4.39 & 0.81 \\
\hline 11. & $\begin{array}{l}\text { Simple mathematical operation } \\
\text { problem solving }\end{array}$ & 4.30 & 0.93 \\
\hline
\end{tabular}

The items 1 until 9 referred to the Low-Order Thinking skills (LOTs) and basic numeracy content learning according to KPSK that would be further enhanced in the early primary-years curriculum. The items 1 to 9 (i.e., numbers writing, comparing objects based on particular characteristics, numbers comparing, classifications of objects, object arranging, identical and non-identical pair object matching, object matching, and number concepts resembled the lists of activities of children to remember, understand and apply the concept that they understood in numeracy. Meanwhile, the items 10 and 11 were the High-Order Thinking Skills (HOTs), including analysing, evaluating, creating through games, and simple arithmetic problem-solving activity. The data revealed that the parents' perceived knowledge about early numeracy was confined towards the cultivation of Low-Order Thinking skills.

\subsection{Parents' Readiness to be Involved in Mathematical Activities at Home}

Table 3 shows the mean and standard deviation of the parents' readiness to be involved in mathematical activities at home by analysing the items 12 to 16 . According to Table 4, most parents self-rated as "Quite Ready" in this construct that focused on parents' readiness to be involved in mathematical activities at home. Based on SPSS data, the item 15 of "I assist my child in mathematics-related problem solving" showed the highest mean value of $\mathrm{M}=4.29(\mathrm{SD}=0.88)$ and the item 13 of "I prepare concrete materials for my child to understand mathematics" indicated the lowest mean value of $\mathrm{M}=3.64(\mathrm{SD}=1.14)$. 
Table 3. Distribution of mean and standard deviation of parents' readiness to be involved in mathematical activities at home

\begin{tabular}{llcc}
\hline No. & Items & Mean (M) & Standard Deviation (SD) \\
\hline 12. & $\begin{array}{l}\text { I prepare mathematics-based } \\
\text { activities for my child at home }\end{array}$ & 3.84 & 1.00 \\
13. & $\begin{array}{l}\text { I prepare concrete materials for my } \\
\text { child to understand mathematics }\end{array}$ & 3.64 & 1.14 \\
$14 . \quad \begin{array}{l}\text { I asked my child questions on } \\
\text { mathematics concepts while doing } \\
\text { activities at home }\end{array}$ & 3.97 & 1.00 \\
15. & $\begin{array}{l}\text { I assist my child in mathematics } \\
\text { related problem solving }\end{array}$ & 4.29 & 0.88 \\
$16 . \quad \begin{array}{l}\text { I sing counting songs with my } \\
\text { child at home }\end{array}$ & 3.68 & 1.24 \\
\hline
\end{tabular}

Parents' readiness to assist their children can be detected through the parents' actions that are done by them in supporting children's learning at home. Even though the parents have prepared the material to learn at home, the preparation seemingly focused on non-concrete materials such as asking mathematics questions and assisting in problem-solving. On the contrary to the earlier findings, these data indicated that even though parents believed that they have limited content knowledge related to early numeracy problem solving, they were dedicated to assist their children in this area. However, the least non-concrete learning material rated by parents was singing counting song activity.

\subsection{Parents' Understanding of the Importance of Mathematics}

By referring to Table 4, parents had a high understanding of the importance of mathematics measured through items 17 to 26 . The item 17, "numbers writing," showed the highest mean value of $\mathrm{M}=4.78$ ( $\mathrm{SD}=0.56$ ), while the item 23 of "doing exercises with other children" indicated the lowest mean value of $\mathrm{M}=4.49$ (SD = 0.92). More than $70 \%$ of respondents rated "very important" for all items in this construct except $64.5 \%$ on the item 25 , which was "doing exercises with materials/games."

Table 4. Distribution of mean and standard deviation of parents' understanding of the importance of mathematics

\begin{tabular}{llcc}
\hline No. & Items & Mean (M) & $\begin{array}{c}\text { Standard Deviation } \\
(\mathrm{SD})\end{array}$ \\
\hline 17. & Writing numbers & 4.78 & 0.56 \\
18. & $\begin{array}{l}\text { Comparing objects based on } \\
\text { particular characteristics }\end{array}$ & 4.68 & 0.63 \\
19. & $\begin{array}{l}\text { Comparing numbers } \\
\text { 20. }\end{array}$ & 4.76 & 0.55 \\
& $\begin{array}{l}\text { Classification of objects based on } \\
\text { particular characteristics }\end{array}$ & 4.69 & 0.62 \\
21. & Arranging object based on particular & 4.72 & 0.59 \\
& criteria & & \\
22. & Mathematical games & 4.59 & 0.81 \\
23. & Doing exercises with other children & 4.49 & 0.92
\end{tabular}




\begin{tabular}{llll} 
24. & Doing homework/exercises & 4.65 & 0.69 \\
25. & Doing exercises with & 4.47 & 0.85 \\
& materials/games & & \\
26. & Simple problem solving & 4.60 & 0.80 \\
\hline
\end{tabular}

Based on the findings, most parents grasped the mathematical importance by employing behaviourist task-based exercise. Even with a small sparsity, the games and inter-child activities were not seen as part of learning mathematics than rote learning (write and compare numbers, compare and classify objects based on particular characteristics). The finding was in line with the lowest score in parents' perceived knowledge in exercising using activities with learning materials and/or games and in parents' readiness to prepare concrete material. The consistent emergence in terms of games and material-based activity in the home environment has predicted instructional knowledge of underlying issue among parents.

\subsection{Parents' Experience in Mathematics}

As compared to the five-point scale in the parents' knowledge, understanding, and attitude constructs, the parents' experience in mathematics was to identify the perception of mathematics-related-past schooling experience using three point-Likert scales (Table 5). Based on the Table 5, the lowest mathematics experience score was in item $27(\mathrm{M}=1.21)$. Meanwhile, the experience in secondary school mathematics was rated at the highest $(M=1.40)$.

Table 5. Distribution of mean and standard deviation of parents' experience in mathematics

\begin{tabular}{llcc}
\hline No. & Items & Mean (M) & $\begin{array}{c}\text { Standard Deviation } \\
(\mathrm{SD})\end{array}$ \\
\hline 27. & My opinion about mathematics & 1.21 & 0.48 \\
28. & $\begin{array}{l}\text { My experience in primary school } \\
\text { mathematics }\end{array}$ & 1.22 & 0.50 \\
29. & $\begin{array}{l}\text { My experience in secondary school } \\
\quad \text { mathematics }\end{array}$ & 1.40 & 0.62 \\
30. & My confidence in mathematics & 1.31 & 0.61 \\
31. & My ability in mathematics & 1.31 & 0.59 \\
\hline
\end{tabular}

The overall finding of the parents' experience was centered at the midpoint. Thus, this evidence debunked that most parents' mathematics experiences during their school days were moderately scored. The findings were unlikely to complement with the demographic profile of the parents who participated in this study. Although most parents attained the basic secondary education, their experience with mathematics during schooling was moderate.

\subsection{Parents' Attitudes towards Mathematics}

As presented in Table 6, parents' attitudes towards mathematics were relatively moderate. Based on the finding, item 32 of "only teachers are responsible to teach my children about mathematics," and item 33 of "parents are solely responsible to teach my children about mathematics" showed the lowest mean value, which was $\mathrm{M}=1.87(\mathrm{SD}=1.29)$ and followed by $\mathrm{M}=1.73(\mathrm{SD}=1.17)$. The two lowest 
scored items underpinned the idea that a child's early numeracy was bothparents' and teachers' responsibility. From the finding of item 34 till 39, most parents had a positive attitude in facilitating their children's numeracy.

Table 6. Distribution of mean and standard deviation of the parents' experience in mathematics

\begin{tabular}{llcc}
\hline No. & Items & Mean (M) & $\begin{array}{c}\text { Standard } \\
\text { Deviation (SD) }\end{array}$ \\
\hline 32. & $\begin{array}{l}\text { Only teachers are responsible to teach my } \\
\text { children about mathematics }\end{array}$ & 1.87 & 1.29 \\
33. $\quad \begin{array}{l}\text { Parents are solely responsible to teach my } \\
\text { children about mathematics }\end{array}$ & 1.73 & 1.17 \\
34. $\quad \begin{array}{l}\text { Activities in the home could be related to } \\
\text { mathematics }\end{array}$ & 4.07 & 1.09 \\
35. $\quad \begin{array}{l}\text { All children have the opportunity to } \\
\text { excel/succeed in mathematics }\end{array}$ & 4.59 & 0.76 \\
36. $\quad \begin{array}{l}\text { I can assist my child to enhance } \\
\text { mathematical knowledge }\end{array}$ & 4.33 & 0.86 \\
37. $\quad \begin{array}{l}\text { My involvement in learning will enhance } \\
\text { my child's positive attitudes towards } \\
\text { mathematics }\end{array}$ & 4.35 & 0.68 \\
38. $\quad \begin{array}{l}\text { It is important for children to have fun } \\
\text { while learning mathematics }\end{array}$ & 4.66 & 0.83 \\
39. $\quad \begin{array}{l}\text { I have a role in inculcating positive } \\
\text { attitudes towards mathematics among } \\
\text { children }\end{array}$ & 4.39 & \\
\hline
\end{tabular}

\subsection{Parental Involvement in Young Children's Learning of Numeracy}

The mean values of all constructs are tabulated in Table 7 to view the overall finding of this study.

Table 7. The descriptive statistics of all constructs

\begin{tabular}{lcccccc} 
& $\begin{array}{c}\text { Number } \\
\text { of items }\end{array}$ & Min & Max & $\begin{array}{c}\text { Mean } \\
(\mathrm{M})\end{array}$ & $\begin{array}{c}\text { Percentage } \\
(\%)\end{array}$ & $\begin{array}{c}\text { Likert- } \\
\text { scale } \\
\text { point }\end{array}$ \\
\hline $\begin{array}{l}\text { Constructs } \\
\begin{array}{l}\text { Parents' knowledge about } \\
\text { preschool mathematics }\end{array}\end{array}$ & 11 & 4.30 & 4.65 & 4.54 & 93.0 & 5 \\
$\begin{array}{l}\text { Parents' readiness to involve in } \\
\text { mathematical activities at home }\end{array}$ & 5 & 3.64 & 4.29 & 3.88 & 77.6 & 5 \\
$\begin{array}{l}\text { Parents' understanding of the } \\
\text { importance of mathematics }\end{array}$ & 10 & 4.47 & 4.78 & 4.64 & 92.8 & 5 \\
$\begin{array}{l}\text { Parents' experience in mathematics } \\
\begin{array}{l}\text { Parents' attitudes towards } \\
\text { mathematics }\end{array}\end{array}$ & 5 & 1.21 & 1.40 & 1.29 & 43.0 & 3 \\
\hline
\end{tabular}

From the data, three constructs with five point-Likert scales mean were more than $M=4.5$. The finding indicated that parents had high perceived knowledge about preschool mathematics; parents are ready to be involved in mathematical activities at home; and parents understand that mathematics are vital for their children. Considering the three-point Likert scale to measure the fourth construct, 
the $M=1.29$ highlighted that the parents encountered moderate mathematics experience. Finally, the mean $(M=3.75)$ of the fifth construct showed that parents had moderate attitude towards mathematics. The mean percentages of all constructs are presented in Figure 1.

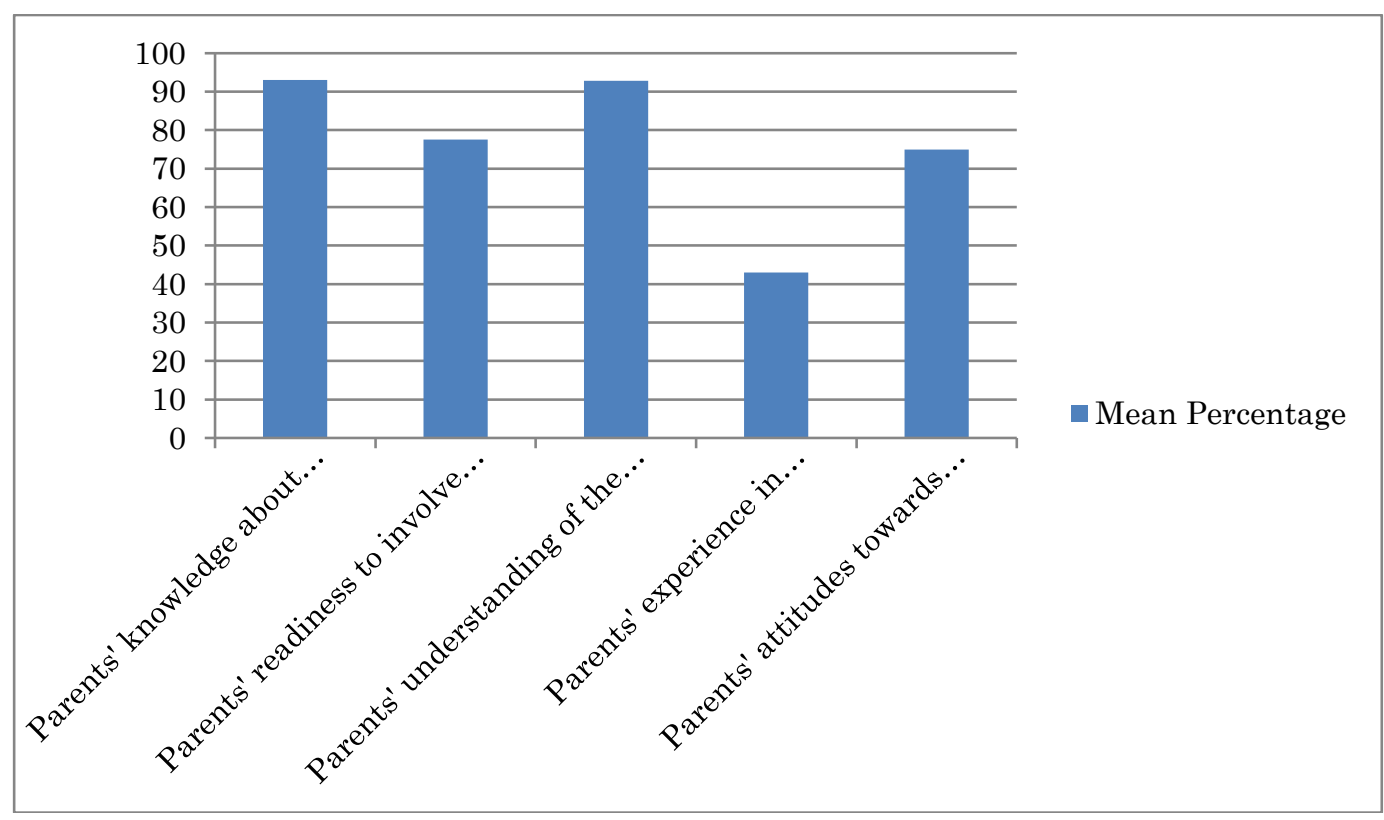

Figure 2. The descriptive statistics of all constructs

\section{Discussion}

The parental involvement was measured through five constructs consisted of parents' knowledge about preschool mathematical practices and curriculum, parents' readiness to be involved in mathematical activities at home, parents' understanding, experience, and attitudes towards numeracy and number concepts. It was found out that parents' knowledge, understanding, and attitude towards preschoolers' numeracy was high. Parents also had moderate experience and attitudes toward mathematics.

In this study, most parents perceived that mathematics is essential and willing to get involved in their children's numeracy activity. From the analysis throughout 39 items, overall, the parents in this study preferred to advance the operational activities, LOT's-levelled, non-concrete, indirect activities, behaviourist-task based activities. The finding was similar to Susperreguy et al. (2018), Ramani et al. (2015), and Sobayi (2018), who studied the early numeracy in primary-schooled children, the parent-child interaction in numeracy was limited at an operational basic-level and inclined towards the advancement of current development stage and improvement to prepare for primary years schooling. Soto-Calvo et al. (2020) and Kleemans et al. (2012) also found that the parents tended to be involved in task-based behaviourist activity and promote the rote-learning of LOTs. Nevertheless, advancing beyond the children's current development stage is heavily criticised by early childhood researchers (Gersten, Jayanthi \& Dimino, 2017; Little \& Cohen-Vogel, 2016). Therefore, there is a requirement for systematic guidelines and consultation for parents in facilitating advanced numeracy 
principles by manifesting HOTs and tool-aided numeracy activity (Linder \& Emerson 2019; Smith et al., 2020) to facilitate an effective the parents' involvement in numeracy learning.

Despite moderate positive self-experience in mathematics, encouragingly, parents showed their confidence that they have substantial mathematical knowledge and ready to impose on mathematics importance for their children. Based on this study, there was a requirement for a deeper understanding of the parents with moderate experience and attitude in mathematic that encouraged children's early numeracy at home. To sum, we believe that the parents had some driving forces to assist their children in numeracy at home regardless of the moderate experience and attitudes toward mathematics. Nevertheless, the factors that drive the parents to be involved in their children's numeracy activity need to be further studied.

\section{Conclusion}

This study has provided new tangents of perceived reality in parental numeracy involvement in the Malaysian context. From the finding, there is an evident that the parents had already an awareness of their involvement in early numeracy. Parents should be supported by 'how to facilitate the home early numeracy' rather than 'what to teach at home.' The pedagogical knowledge, instructional strategies, and the psychology of child development as the principles of home-numeracy are essentially required to conduct effective home-based learning. Thus, this research was the indication for the policymaker to design a systematic program for parents in engaging with their children at home.

The present study has discrepant views of self-rating with reality. The survey methodology was prone to self-rating bias and social desirability issues, affecting the finding practical and vocational circumstances. Henceforth, the follow-up study which measures parental involvement is suggested to include a comprehensive measure to examine parents' economic status and motivational factors to be involved with their children's numeracy activity at home. Besides, the frequency, quality, and extent of parental involvement will better understand the potential instructional strategies to be introduced to the parents; which in turn refers to the limitation of this study. The local circumstances and cultural factors also require to be further studied in the Malaysian multicultural context to assure for a numerate citizen.

\section{Acknowledgement}

This research project was sponsored by Exploratory Research Grant Scheme (ERGS) Grant No: 203/PGURU/6730128 by Ministry of Education, Malaysia.

\section{References}

Aunio, P., Mononen, R., Ragpot, L., \& Törmänen, M. (2016). Early Numeracy Performance of South African School Beginners. South African Journal of Childhood Education, 6(1), 496. http://doi.org/10.4102/sajce.v6i1.496

Ayonrinde, O. A., Stefatos, A., Miller, S., Richer, A., Nadkarni, P., She, J., \& Mngoma, N. (2020). The salience and symbolism of numbers across cultural beliefs and practice. International Review of Psychiatry, 1-10. http://doi.org/10.1080/09540261.2020.1769289 
Baccaglini-Frank, A., Carotenuto, G., \& Sinclair, N. (2020). Eliciting preschoolers' number abilities using open, multi-touch environments. ZDM, 1-13. http://doi.org/10.1007/s11858-020-01144-y

Curriculum Development Centre. (2010). Kurikulum Standard Prasekolah Kebangsaan [National Preschool Curriculum Standard]. Malaysia Kementerian Pelajaran Malaysia.

Balt, M., Fritz, A., \& Ehlert, A. (2020). Insights into First Grade Students' Development of Conceptual Numerical Understanding as Drawn From Progression-Based Assessments. Frontiers in Education, 5(80), 1-11. http://doi.org/10.3389/feduc.2020.00080

Barrera-Mora, F., \& Reyes-Rodriguez, A. (2019). Fostering Middle School Students Number Sense Through Contextualized Tasks. International Electronic Journal of Elementary Education, 12(1), 75-86. http://doi.org/10.26822/iejee.2019155339

Bennison, A. (2019). Numeracy across the Curriculum in Initial Teacher Education. Mathematics Education Research Group of Australasia. https://eric.ed.gov/?id=ED604179

Brandlistuen, R. E., Flatø, M., Stoltenberg, C., Helland, S. S., \& Wang, M. V. (2020). Gender gaps in preschool age: A study of behavior, neurodevelopment and pre-academic skills. Scandinavian Journal of Public Health, 140349482094474. http:/ / doi.org/10.1177/1403494820944740

Brueggemann, A., \& Gable, S. (2018). Preschoolers' selective sustained attention and numeracy skills and knowledge. Journal of Experimental Child Psychology, 171, 138147. http:// doi.org/10.1016/j.jecp.2018.02.001

Burns, P. M. (2020). Maternal Education, Home Environment, and Educational Aspirations: The Relationship with Children's Math Skills [Doctoral dissertation]. Teachers College, Columbia University.

West, J., \& Budgen, F. (2020). Foundations of Primary Mathematics Education An introduction to curriculum, pedagogy and content. http:// doi.org/10.4324/9781003115694

Bull, R., Davidson, W. A., \& Nordmann, E. (2010). Prenatal testosterone, visual-spatial memory, and numerical skills in young children. Learning and Individual Differences, 20(3), 246-250. http:// doi.org/10.1016/j.lindif.2009.12.002

Cahoon, A., Cassidy, T., \& Simms, V. (2017). Parents' views and experiences of the informal and formal home numeracy environment. Learning, Culture and Social Interaction, 15, 69-79. http://doi.org/10.1016/j.lcsi.2017.08.002

Clayton, S., \& Gilmore, C. (2014). Inhibition in dot comparison tasks. ZDM, 47(5), 759-770. http://doi.org/10.1007/s11858-014-0655-2

Cohen, P. C. (2001). The emergence of numeracy. Mathematics and democracy: The case for quantitative literacy, 23-30. https://www.montclair.edu/facultyadvancement/wp-content/uploads/sites/195/2020/02/MathAndDemocr acy

Cui, Y., Zhang, D., \& Leung, F. K. (2019). The Influence of Parental Educational Involvement in Early Childhood on 4th Grade Students' Mathematics Achievement. Early Education and Development, 1-21. http://doi.org/10.1080/10409289.2019.1677131

Darriet, E., Guille, M., Vergnaud, J.-C., \& Shimizu, M. (2020). Money illusion, financial literacy and numeracy: Experimental evidence. Journal of Economic Psychology, 76, 102211. http:// doi.org/10.1016/j.joep.2019.102211

DeFlorio, L., \& Beliakoff, A. (2015). Socioeconomic status and preschoolers' mathematical knowledge: The contribution of home activities and parent beliefs. Early Education and Development, 26(3), 319-341. http://doi.org/10.1080/10409289.2015.968239 
Díez-Palomar, J. (2019). Dialogic mathematics gatherings: encouraging the other women's critical thinking on numeracy. ZDM, 52(3), 473-487. http://doi.org/10.1007/s11858-019-01092-2

Drummond, K. V., \& Stipek, D. (2004). Low-income parents' beliefs about their role in children's academic learning. The elementary school journal, 104(3), 197-213. http://doi.org/10.1086/499749

Edens, K. M., \& Potter, E. F. (2012). An Exploratory Look at the Relationships Among Math Skills, Motivational Factors and Activity Choice. Early Childhood Education Journal, 41(3), 235-243. http:// doi.org/10.1007/s10643-012-0540-y

Education Policy Planning and Research Division (2021). Pengurusan Permohonan Data Pendidikan, Bahagian Perancangan Dan Penyelidikan Dasar Pendidikan, Kementerian Pelajaran Malaysia [Educational Data Application Management, Education Policy Planning and Research Division, Ministry of Education, Malaysia]. https://www.moe.gov.my/korporat/bahagian-dan-unit/bahagianperancangan-dan-penyelidikan-dasar-pendidikan

Finn, L., \& Vandermaas-Peeler, M. (2013). Young Children's Engagement and Learning Opportunities in a Cooking Activity with Parents and Older Siblings. Early Childhood Research \& Practice, 15(1).

Forgasz, H., \& Leder, G. (2020). The NAPLAN numeracy test: do school type and socioeconomic background make a difference? Mathematics Education Research Journal. http:// doi.org/10.1007/s13394-020-00326-x

Galindo, C., \& Sonnenschein, S. (2015). Decreasing the SES math achievement gap: Initial math proficiency and home learning environments. Contemporary Educational Psychology, 43, 25-38. http://doi.org/10.1016/j.cedpsych.2015.08.003

Gersten, R., Jayanthi, M., \& Dimino, J. (2017). Too Much, Too Soon? Unanswered Questions From National Response to Intervention Evaluation. Exceptional Children, 83(3), 244-254. http://doi.org/10.1177/0014402917692847

Ghazali, M., Ismail, Z., Rashid, R. A. A., Amzah, F., \& Ashari, Z. M., (2017). Monograph Exploring the Knowledge Gap in Learning Numeracy before Formal Schooling. The collection of Closed Access Repository@USM Monograph from School of Educational Studies. Basic Education Research Unit (BERU). http://ethesis.usm.my/jspui/handle/123456789/4479.

Goos, M., Geiger, V., Dole, S., Forgasz, H., \& Bennison, A. (2020). Numeracy opportunities. Numeracy Across the Curriculum. In Numeracy Across the Curriculum: Researchbased strategies for enhancing teaching and learning (pp. 103-127). Routledge. http:// doi.org/10.4324/9781003116585-5

Hannula-Sormunen, M. M., Lehtinen, E., \& Räsänen, P. (2015). Preschool Children's Spontaneous Focusing on Numerosity, Subitizing, and Counting Skills as Predictors of Their Mathematical Performance Seven Years Later at School. Mathematical Thinking and Learning, 17(2-3), 155-177. http://doi.org/10.1080/10986065.2015.1016814

Harun, J., Ghazali, M., Abd Hamid, Z. B., \& Nasir, M. I. M. (2017). Content of Early Numeracy in the Malaysian Preschools. International Journal of Academic Research in Business and Social Sciences, 7(2), 477-485. https://hrmars.com/hrmars_papers/Content_of_Early_Numeracy_in_the_Mal aysian_Preschools.pdf

Husen, S. D., \& Mansor, R. (2018). Parents Involvement in Improving Character of Children Through Mathematics Learning. Jurnal Ilmiah Peuradeun, 6(1), 41. http://doi.org/10.26811/peuradeun.v6i1.178 
Kleemans, T., Peeters, M., Segers, E., \& Verhoeven, L. (2012). Child and home predictors of early numeracy skills in kindergarten. Early Childhood Research Quarterly, 27(3), 471-477. http://doi.org/10.1016/j.ecresq.2011.12.004

Kesler, S. R., Sheau, K., Koovakkattu, D., \& Reiss, A. L. (2011). Changes in frontal-parietal activation and math skills performance following adaptive number sense training: Preliminary results from a pilot study. Neuropsychological Rehabilitation, 21(4), 433-454. http:// doi.org/10.1080/09602011.2011.578446

Koponen, T., Aunola, K., \& Nurmi, J. E. (2019). Verbal counting skill predicts later math performance and difficulties in middle school. Contemporary Educational Psychology, 59. http://doi.org/10.1016/j.cedpsych.2019.101803

Lin, J., Litkowski, E., Schmerold, K., Elicker, J., Schmitt, S. A., \& Purpura, D. J. (2019). Parent-Educator Communication Linked to More Frequent Home Learning Activities for Preschoolers. Child \& Youth Care Forum, 48(5), 757-772. http://doi.org/10.1007/s10566-019-09505-9

Linder, S. M., \& Emerson, A. (2019). Increasing Family Mathematics Play Interactions Through a Take-Home Math Bag Intervention. Journal of Research in Childhood Education, 33(3), 323-344. http:// doi.org/10.1080/02568543.2019.1608335

Little, M. H., \& Cohen-Vogel, L. (2016). Too much too soon? An analysis of the discourses used by policy advocates in the debate over kindergarten. Education Policy Analysis Archives, 24, 106. http://doi.org/10.14507/epaa.24.2293

Lore, M. D., Wang, A. H., \& Buckley, M. T. (2016). Effectiveness of a Parent-Child Home Numeracy Intervention on Urban Catholic School First Grade Students. Journal of Catholic Education, 19(3), 142-165. http:// doi.org/10.15365/joce.1903082016

Martin, A. J., \& Lazendic, G. (2018). Achievement in large-scale national numeracy assessment: An ecological study of motivation and student, home, and school predictors. Journal of Educational Psychology, 110(4), 465-482.

Muir, T. (2012). Numeracy at home: Involving parents in mathematics education. International Journal for Mathematics Teaching and Learning, 1-13. http://www.cimt.org.uk/journal/muir.pdf

Mutaf-Yıldız, B., Sasanguie, D., De Smedt, B., \& Reynvoet, B. (2019). Probing the relationship between home numeracy and children's mathematical skills: A systematic search and review. H0m3is where Num3r4cyis! [Doctoral dissertation]. University of Leuven. http://doi.org/10.3389/fpsyg.2020.02074

Napoli, A. R., \& Purpura, D. J. (2018). The home literacy and numeracy environment in preschool: Cross-domain relations of parent-child practices and child outcomes. Journal of Experimental Child Psychology, 166, 581-603. http:// doi.org/10.1016/j.jecp.2017.10.002

Ng, K. T., Lay, Y. F., Areepattamannil, S., Treagust, D. F., \& Chandrasegaran, A. L. (2012). Relationship between affect and achievement in science and mathematics in Malaysia and Singapore. Research in Science \& Technological Education, 30(3), 225237. http:// doi.org/10.1080/02635143.2012.708655

Pantsar, M. (2019). Mathematical cognition and enculturation: introduction to the Synthese special issue. Synthese, 197(9), 3647-3655. http://doi.org/10.1007/s11229-019-02478-1

Peng, C. F., Leng, C. H., \& Hutagalung, F. (2016, August 1-2). Implementation of the LINUS program in Malaysian primary schools. Proceedings of the Annual International Conference on Management and Technology in Knowledge, Service, Tourism \& Hospitality 2015 (SERVE 2015), Bandung, Indonesia. 
Piper, B., Simmons Zuilkowski, S., Dubeck, M., Jepkemei, E., \& King, S. J. (2018). Identifying the essential ingredients to literacy and numeracy improvement: Teacher professional development and coaching, student textbooks, and structured teachers' guides. World Development, 106, 324-336. http://doi.org/10.1016/j.worlddev.2018.01.018

Purpura, D. J., King, Y. A., Rolan, E., Hornburg, C. B., Schmitt, S. A., Hart, S. A., \& Ganley, C. M. (2020). Examining the Factor Structure of the Home Mathematics Environment to Delineate Its Role in Predicting Preschool Numeracy, Mathematical Language, and Spatial Skills. Frontiers in Psychology, 11. http://doi.org/10.3389/fpsyg.2020.01925

Raghubar, K. P., \& Barnes, M. A. (2016). Early numeracy skills in preschool-aged children: a review of neurocognitive findings and implications for assessment and intervention. The Clinical Neuropsychologist, 31(2), 329-351. http://doi.org/10.1080/13854046.2016.1259387

Ramani, G. B., Rowe, M. L., Eason, S. H., \& Leech, K. A. (2015). Math talk during informal learning activities in Head Start families. Cognitive Development, 35, 15-33. http://doi.org/10.1016/j.cogdev.2014.11.002

Rogers, S. L., Barblett, L., \& Robinson, K. (2018). Parent and teacher perceptions of NAPLAN in a sample of Independent schools in Western Australia. The Australian Educational Researcher, 45(4), 493-513. http://doi.org/10.1007/s13384-018-0270-2

Sharp, H. (2017). History and the Importance of Numeracy. Numeracy in Authentic Contexts, 257-284. Springer. http://doi.org/10.1007/978-981-10-5736-6_12

Silinskas, G., Di Lonardo, S., Douglas, H., Xu, C., LeFevre, J.A., Garckija, R., Raiziene, S. (2020). Responsive home numeracy as children progress from kindergarten through Grade 1. Early Childhood Research Quarterly, 53, 484-495. http://doi.org/10.1016/j.ecresq.2020.06.003

Silva, D., Colvin, L., Glauert, R., Stanley, F., Srinivasjois, R., \& Bower, C. (2015). Literacy and Numeracy Underachievement in Boys and Girls With ADHD. Journal of Attention Disorders, 24(9), 1305-1316. http://doi.org/10.1177/1087054715596575

Singer, V., \& Strasser, K. (2017). The association between arithmetic and reading performance in school: A meta-analytic study. School Psychology Quarterly, 32(4), 435. http://doi.org/10.1037/spq0000197

Singh, P., Rahman, N. A., Ramly, M. A., \& Sian Hoon, T. (2019). From Nonsense to Number Sense: Enumeration of Numbers in Math Classroom Learning. The European Journal of Social $\mathcal{E}$ Behavioural Sciences, 25(2), 2933-2947. http://doi.org/10.15405/ejsbs.256

Skwarchuk, S.-L., Vandermaas-Peeler, M., \& LeFevre, J. A. (2016). Optimizing the home numeracy environments of 3- to 6-year-old children in the USA and Canada. In B. Blevins-Knabe \& A. M. B. Austin (Eds.), Early childhood mathematics skill development in the home environment (pp. 127-146). Springer International Publishing. http://doi.org/10.1007/978-3-319-43974-7_8

Smith, T. E., Holmes, S. R., Sheridan, S. M., Cooper, J. M., Bloomfield, B. S., \& Preast, J. L. (2020). The Effects of Consultation-based Family-school Engagement on Student and Parent Outcomes: A Meta-analysis. Journal of Educational and Psychological Consultation, 1-29. http:// doi.org/10.1080/10474412.2020.1749062

Sobayi, C. (2018). The role of parents and pre-primary education in promoting early numeracy development to young children in Dar es Salaam. Papers in Education and Development, $35 . \quad$ http://196.44.162.39/index.php/ped /article/view/1487/1393 
Sobkow, A., Olszewska, A., \& Traczyk, J. (2020). Multiple numeric competencies predict decision outcomes beyond fluid intelligence and cognitive reflection. Intelligence, 80, 101452. http://doi.org/10.1016/j.intell.2020.101452

Son, S.-H. C., \& Hur, J. H. (2020). Parental Math Talk During Home Cooking and Math Skills in Head Start Children: The Role of Task Management Talk. Journal of Research in Childhood Education, 34(3), 406-426. http:/ / doi.org/10.1080/02568543.2019.1704318

Sonnenschein, S., Galindo, C., Metzger, S. R., Thompson, J. A., Huang, H. C., \& Lewis, H. (2012). Parents' beliefs about children's math development and children's participation in math activities. Child Development Research, 2012. http://doi.org/10.1155/2012/851657

Soto-Calvo, E., Simmons, F. R., Adams, A.-M., Francis, H. N., Patel, H., \& Giofrè, D. (2020). Identifying the preschool home learning experiences that predict early number skills: Evidence from a longitudinal study. Early Childhood Research Quarterly, 53, 314-328. http://doi.org/10.1016/j.ecresq.2020.04.004

Susperreguy, M. I., Di Lonardo Burr, S., Xu, C., Douglas, H., \& LeFevre, J. (2020). Children's Home Numeracy Environment Predicts Growth of their Early Mathematical Skills in Kindergarten. Child Development, 91(5), 1663-1680. http://doi.org/10.1111/cdev.13353

Susperreguy, M. I., Douglas, H., Xu, C., Molina-Rojas, N., \& LeFevre, J.-A. (2020). Expanding the Home Numeracy Model to Chilean children: Relations among parental expectations, attitudes, activities, and children's mathematical outcomes. Early Childhood Research Quarterly, 50, 16-28. http:// doi.org/10.1016/j.ecresq.2018.06.010

Tosto, M. G., Petrill, S. A., Halberda, J., Trzaskowski, M., Tikhomirova, T. N., Bogdanova, O. Y., Kovas, Y. (2014). Why do we differ in number sense? Evidence from a genetically sensitive investigation. Intelligence, 43, 35-46.

Ubale, A. Z., \& Abdullah, A. H. (2015, June 6-7). A Relationship Between Parental Involvement and Learning Achievment of Islamic Education in National Religious Secondary Schools Kuala Terengganu Malaysia. Proceedings of ICIC2015 - International Conference on Empowering Islamic Civilization in the 21st Century. Universiti Sultan Zainal Abidin, Malaysia. eISBN: 978-967-13705-0-6

Vacher, H. L. (2014). Looking at the Multiple Meanings of Numeracy, Quantitative Literacy, and Quantitative Reasoning. Numeracy, 7(2). http://doi.org/10.5038/1936-4660.7.2.1

Vandermaas-Peeler, M., Westerberg, L., \& Fleishman, H. (2019). Bridging known and new: Inquiry and intersubjectivity in parent-child interactions. Learning, Culture and Social Interaction, 21, 124-135. http:// doi.org/10.1016/j.lcsi.2019.02.011

Vandermaas-Peeler, M., Massey, K., \& Kendall, A. (2015). Parent Guidance of Young Children's Scientific and Mathematical Reasoning in a Science Museum. Early Childhood Education Journal, 44(3), 217-224. http://doi.org/10.1007/s10643-0150714-5

Vandervert, L. (2017). The Origin of Mathematics and Number Sense in the Cerebellum: with Implications for Finger Counting and Dyscalculia. Cerebellum \& Ataxias, 4(1). http://doi.org/10.1186/s40673-017-0070-x

Visser, M. M., Juan, A. L., \& Hannan, S. M. (2019). Early learning experiences, school entry skills and later mathematics achievement in South Africa. South African Journal of Childhood Education, 9(1). http:/ / doi.org/10.4102/sajce.v9i1.597

Vygotsky, L. (1978). Interaction between learning and development. Readings on the development of children, 23(3), 34-41. 
Weerasinghe, D. G. (2017). Parents' Perceptions and Involvement in the Mathematics Education of their Children [Doctoral dissertation]. Monash University.

Wei, Y., \& Hutagalung, F. (2014). LINUS assessment accordance with the cognitive level among year 1 students in a School Klang District. Management and Technology in Knowledge, $\quad$ Service, Tourism $\quad \mathcal{E}$ Hospitality, 123-126. http://doi.org/10.1201/b16700-26

Whitacre, I., Henning, B., \& Atabaș, Șebnem. (2020). Disentangling the Research Literature on Number Sense: Three Constructs, One Name. Review of Educational Research, 90(1), 95-134. http:/ / doi.org/10.3102/0034654319899706

Wilkey, E. D., \& Ansari, D. (2020). Challenging the neurobiological link between number sense and symbolic numerical abilities. Annals of the New York Academy of Sciences, 1464(1), 76-98. http:/ / doi.org/10.1111/nyas.14225

Xu, F., Spelke, E. S., \& Goddard, S. (2005). Number sense in human infants. Developmental Science, 8(1), 88-101. http://doi.org/10.1111/j.1467-7687.2005.00395.x

\section{Appendix 1}

\section{Appendices}

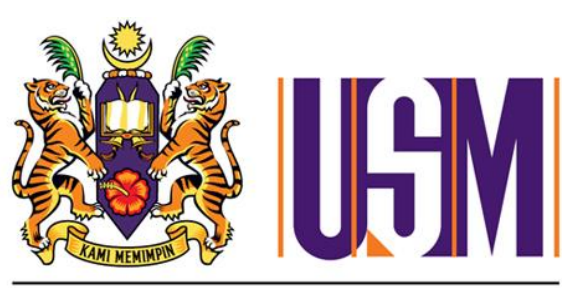

UNIVERSITI SAINS MALAYSIA

Meneroka Pengetahuan Pembelajaran Numerasi Sebelum Persekolahan Formal

Exploring Knowledge in Learning Numeracy

Before Formal Schooling

Pusat Pengajian Ilmu Pendidikan, Universiti Sains Malaysia

Geran ERGS (Grant No: 203/PGURU/6730128)

Kementerian Pelajaran Malaysia

Universiti Sains Malaysia

$2013-2015$

\section{Instrument}

Soal Selidik Ibu Bapa

Parents' Quentionnaire 
BAHAGIAN A : DEMOGRAFI

Maklumat Ibu Bapa

SECTION A : DEMOGRAPHY

Parents' Information

Tarikh

Date

Jantina

Gender

Lelaki/Male

Perempuan/ Female

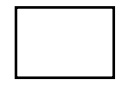

Etnik

Ethnic

: Malay

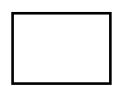

Chinese

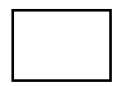

India

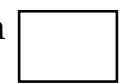

Lain lain/Others :

(sila isikan)

Negeri/State:

Daerah/

Pendidikan/Education

\begin{tabular}{ll|ll}
\multicolumn{2}{c|}{ Ibu/Mother } & \multicolumn{2}{c}{ Bapa/Father } \\
\hline SPM/SPVM & & SPM/SPVM \\
STPM & STPM \\
DIPLOMA & DIPLOMA \\
BACHELOR & BACHELOR \\
MASTER & MASTER \\
PhD & PhD
\end{tabular}

Pekerjaan Ibu

Mother's Occupation :

Pekerjaan Bapa

Father's Occupation : 
BAHAGIAN B

SECTION B

* Pengetahuan Berkaitan Matematik Prasekolah

* Knowledge about preschool mathematics

\begin{tabular}{|c|c|c|c|c|}
\hline No. & $\begin{array}{l}\text { Items } \\
\text { Saya boleh mengajar anak saya perkara berikut: } \\
\text { I am able to teach my child the following: }\end{array}$ & $\begin{array}{c}\text { Tidak } \\
\text { boleh } \\
\text { Incapable } \\
1\end{array}$ & $\begin{array}{l}\text { Tidak Pasti } \\
\text { Not Sure } \\
2\end{array}$ & $\begin{array}{c}\text { Boleh } \\
\text { Capable } \\
3\end{array}$ \\
\hline 1. & $\begin{array}{l}\text { Menulis Nombor } \\
\text { Writing numbers. }\end{array}$ & & & \\
\hline 2. & $\begin{array}{l}\text { Membandingkan Objek } \\
\text { Comparing objects. }\end{array}$ & & & \\
\hline 3 & $\begin{array}{l}\text { Membandingkan Nombor } \\
\text { Comparing Numbers }\end{array}$ & & & \\
\hline 4 & $\begin{array}{l}\text { Mengklasifikasi objek } \\
\text { Classification of objects. }\end{array}$ & & & \\
\hline 5. & $\begin{array}{l}\text { Seriasi } \\
\text { Seriation. }\end{array}$ & & & \\
\hline 6. & $\begin{array}{l}\text { Padanan satu - ke - satu } \\
\text { Matching one-to-one. }\end{array}$ & & & \\
\hline 7. & $\begin{array}{l}\text { Memadankan objek tidak seiras } \\
\text { Matching non-identical pair object }\end{array}$ & & & \\
\hline 8. & $\begin{array}{l}\text { Ukuran mudah } \\
\text { Simple measurement. }\end{array}$ & & & \\
\hline 9. & $\begin{array}{l}\text { Konsep nombor } \\
\text { Number concepts. }\end{array}$ & & & \\
\hline 10. & $\begin{array}{l}\text { Latihan/Aktiviti dengan bahan } \\
\text { pembelajaran/permainan } \\
\text { Exercises/Activities with learning } \\
\text { materials/games }\end{array}$ & & & \\
\hline 11. & $\begin{array}{l}\text { Penyelesaian masalah mudah } \\
\text { Simple problem solving. }\end{array}$ & & & \\
\hline
\end{tabular}


- Kesediaan untuk melibatkan diri dalam aktiviti matematik di rumah

* Readiness to involve in mathematical activities at home

\begin{tabular}{|c|c|c|c|c|}
\hline Bil/No. & Item & $\begin{array}{c}\text { Tidak } \\
\text { Bersedia } \\
\text { Not } \\
\text { Ready } \\
1 \\
\end{array}$ & $\begin{array}{l}\text { Tidak } \\
\text { Pasti } \\
\text { Not Sure } \\
\quad 2 \\
\end{array}$ & $\begin{array}{l}\text { Bersedia } \\
\text { Ready } \\
3\end{array}$ \\
\hline 11. & $\begin{array}{l}\text { Saya menyediakan untuk anak saya aktiviti } \\
\text { berunsurkan matematik di rumah. } \\
\text { I prepare mathematics based activities for my } \\
\text { child at home. }\end{array}$ & & & \\
\hline 12. & $\begin{array}{l}\text { Saya menyediakan untuk anak saya } \\
\text { bahan/peralatan konkrit yang cukup bagi } \\
\text { menguasai matematik. } \\
\\
\text { I prepare enough concrete materials for my } \\
\text { child to understand mathematics. }\end{array}$ & & & \\
\hline 13. & $\begin{array}{l}\text { Saya bersoal jawab dengan anak saya tentang } \\
\text { konsep matematik semasa melakukan aktiviti di } \\
\text { rumah. } \\
\text { I asked my child questions on mathematics } \\
\text { concepts while doing activities at home. }\end{array}$ & & & \\
\hline 14. & $\begin{array}{l}\text { Saya membantu anak saya dalam } \\
\text { menyelesaikan masalah berkaitan matematik. } \\
\text { I assist my child in mathematics related problem } \\
\text { solving. }\end{array}$ & & & \\
\hline 15. & $\begin{array}{l}\text { Saya menyanyi lagu berkaitan } \\
\text { membilang bersama anak ketika di rumah. } \\
\text { I sing counting songs with my child at home. }\end{array}$ & & & \\
\hline
\end{tabular}


* Kefahaman tentang kepentingan numerasi

* Understanding about importance of numeracy

\begin{tabular}{|c|c|c|c|c|}
\hline Bil./Nos. & $\begin{array}{l}\text { Item } \\
\text { Adakah aktiviti berikut penting untuk } \\
\text { meningkatkan pengetahuan numerasi } \\
\text { kanak-kanak prasekolah? } \\
\text { Are the following activities important in } \\
\text { enhancing preschool children's knowledge } \\
\text { about numeracy }\end{array}$ & $\begin{array}{c}\text { Tidak } \\
\text { Penting } \\
\text { Not } \\
\text { important } \\
1 \\
\end{array}$ & $\begin{array}{c}\text { Tidak } \\
\text { Pasti } \\
\text { Not } \\
\text { Sure } \\
2 \\
\end{array}$ & $\begin{array}{l}\text { Penting } \\
\text { Important } \\
3 \\
\end{array}$ \\
\hline 16. & $\begin{array}{l}\text { Membilang nombor. } \\
\text { Counting numbers }\end{array}$ & & & \\
\hline 17. & $\begin{array}{l}\text { Menulis nombor. } \\
\text { Writing numbers }\end{array}$ & & & \\
\hline 18. & $\begin{array}{l}\text { Membandingkan objek dan nombor. } \\
\text { Comparing objects and number }\end{array}$ & & & \\
\hline 19. & $\begin{array}{l}\text { Mengelaskan objek. } \\
\text { Classifying objects. }\end{array}$ & & & \\
\hline 20. & $\begin{array}{l}\text { Membuat padanan objek di persekitaran. } \\
\text { Matching objects in the environment. }\end{array}$ & & & \\
\hline 21. & $\begin{array}{l}\text { Permainan matematik. } \\
\text { Mathematical games. }\end{array}$ & & & \\
\hline 22. & $\begin{array}{l}\text { Melakukan latihan dengan kanak-kanak lain. } \\
\text { Doing exercises with other children. }\end{array}$ & & & \\
\hline 23. & $\begin{array}{l}\text { Melakukan kerja rumah/latihan. } \\
\text { Doing homework/exercises. }\end{array}$ & & & \\
\hline 24. & $\begin{array}{l}\text { Melakukan latihan dengan peralatan/bahan } \\
\text { permainan. } \\
\text { Doing exercises with materials/games. }\end{array}$ & & & \\
\hline 25. & $\begin{array}{l}\text { Menyelesaikan masalah mudah. } \\
\text { Simple problem solving }\end{array}$ & & & \\
\hline
\end{tabular}


Pengalaman dalam matematik/Experience in Mathematics

\begin{tabular}{|c|l|c|c|c|}
\hline Bil./Nos. & \multicolumn{1}{|c|}{ Item } & $\begin{array}{c}\text { Positif } \\
1\end{array}$ & $\begin{array}{c}\text { Tidak } \\
\text { Ingat } \\
2\end{array}$ & $\begin{array}{c}\text { Negative } \\
3\end{array}$ \\
\hline 26. & $\begin{array}{l}\text { Pengalaman saya berkaitan numerasi dalam } \\
\text { matematik. } \\
\text { My opinion about numeracy in mathematics. }\end{array}$ & & & \\
\hline 27. & Pengalaman saya dalam matematik sekolah rendah. & & & \\
\hline 28. & $\begin{array}{l}\text { Pengalaman saya dalam matematik sekolah } \\
\text { menengah. }\end{array}$ & & & \\
\hline 29. & $\begin{array}{l}\text { Keyakinan saya dalam mata pelajaran matematik. } \\
\text { My confidence in mathematics. }\end{array}$ & & & \\
\hline 30. & Kebolehan saya dalam mata pelajaran matematik. & & & \\
\hline
\end{tabular}

\begin{tabular}{|c|c|c|c|c|c|}
\hline$*$ & $\begin{array}{l}\text { Sikap terhadap numerasi } \\
\text { Attitudes towards numeracy }\end{array}$ & & & & \\
\hline $\begin{array}{l}\text { Bil./ } \\
\text { No. }\end{array}$ & $\begin{array}{l}\text { Item } \\
\text { Saya berpendapat bahawa/I think that }\end{array}$ & $\begin{array}{l}\text { Sangat } \\
\text { Tidak } \\
\text { Bersetuju } \\
\text { Strongly } \\
\text { disagree } \\
1\end{array}$ & $\begin{array}{l}\text { Tidak } \\
\text { Bersetuju } \\
\text { Disagree } \\
2\end{array}$ & $\begin{array}{c}\text { Setuju } \\
\text { Agree } \\
3\end{array}$ & $\begin{array}{l}\text { Sangat } \\
\text { Bersetuju } \\
\text { Strongly } \\
\text { agree } \\
4\end{array}$ \\
\hline 31. & $\begin{array}{l}\text { Hanya guru sahaja yang } \\
\text { bertanggungjawab mengajar anak saya } \\
\text { tentang numerasi. } \\
\text { Only teachers are responsible to teach my } \\
\text { children about numeracy. }\end{array}$ & & & & \\
\hline 32. & $\begin{array}{l}\text { Aktiviti yang dilakukan di rumah dapat } \\
\text { dikaitkan dengan numerasi. } \\
\text { Activities in the home could be related to } \\
\text { numeracy. }\end{array}$ & & & & \\
\hline 33. & $\begin{array}{l}\text { Semua kanak-kanak berpeluang untuk } \\
\text { berjaya dalam matematik. } \\
\text { All children have the opportunity to } \\
\text { excel/succeed in mathematics. }\end{array}$ & & & & \\
\hline 34. & $\begin{array}{l}\text { Saya boleh membantu anak saya } \\
\text { meningkatkan pengetahuan matematik. } \\
\\
\text { I can assist my child to enhance } \\
\text { mathematical knowledge. }\end{array}$ & & & & \\
\hline 35. & $\begin{array}{l}\text { Penglibatan saya dalam pembelajaran } \\
\text { dapat meningkatkan/menerap sikap } \\
\text { positif anak terhadap matematik. } \\
\text { My involvement in learning will enhance } \\
\text { my child's positive attitudes towards } \\
\text { mathematics. }\end{array}$ & & & & \\
\hline
\end{tabular}




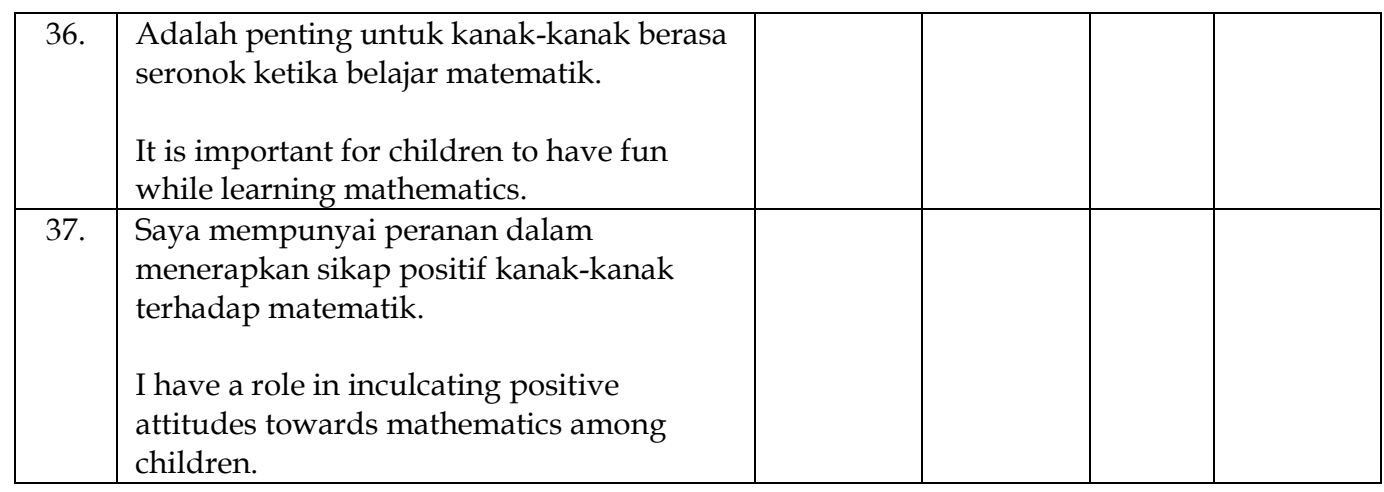

\begin{tabular}{|c|c|c|c|c|c|c|c|c|c|c|c|}
\hline No. & $\begin{array}{l}\text { Items } \\
\text { Sila berikan kepentingan 1(paling kurang } \\
\text { penting) - } 10 \text { (paling penting) untuk item } \\
\text { berikut. } \\
\text { Please rank from 1(least importance) - } 10 \\
\text { (most importance) the following items }\end{array}$ & \multicolumn{10}{|c|}{$\begin{array}{c}\text { Kepentingan (sila bulatkan) } \\
\text { Rank (please circle) } \\
\text { 1(paling kurang penting) - } 10 \text { (paling penting) } \\
\text { (1least importance) - } 10 \text { (most importance) }\end{array}$} \\
\hline 1. & $\begin{array}{l}\text { Menulis Nombor } \\
\text { Writing numbers. }\end{array}$ & 1 & 2 & 3 & 4 & 5 & 6 & 7 & 8 & 9 & 10 \\
\hline 2. & $\begin{array}{l}\text { Membandingkan Objek dan Nombor } \\
\text { Comparing objects and numbers. }\end{array}$ & 1 & 2 & 3 & 4 & 5 & 6 & 7 & 8 & 9 & 10 \\
\hline 3. & $\begin{array}{l}\text { Mengklasifikasi objek } \\
\text { Classification of objects. }\end{array}$ & 1 & 2 & 3 & 4 & 5 & 6 & 7 & 8 & 9 & 10 \\
\hline 4. & $\begin{array}{l}\text { Seriasi } \\
\text { Seriation. }\end{array}$ & 1 & 2 & 3 & 4 & 5 & 6 & 7 & 8 & 9 & 10 \\
\hline 5. & $\begin{array}{l}\text { Padanan satu - ke - satu } \\
\text { Matching one-to-one. }\end{array}$ & 1 & 2 & 3 & 4 & 5 & 6 & 7 & 8 & 9 & 10 \\
\hline 6. & $\begin{array}{l}\text { Memadankan objek dan persekitaran } \\
\text { Matching objects in the environment. }\end{array}$ & 1 & 2 & 3 & 4 & 5 & 6 & 7 & 8 & 9 & 10 \\
\hline 7. & $\begin{array}{l}\text { Ukuran mudah } \\
\text { Simple measurement. }\end{array}$ & 1 & 2 & 3 & 4 & 5 & 6 & 7 & 8 & 9 & 10 \\
\hline 8. & $\begin{array}{l}\text { Konsep nombor } \\
\text { Number concepts. }\end{array}$ & 1 & 2 & 3 & 4 & 5 & 6 & 7 & 8 & 9 & 10 \\
\hline 9. & $\begin{array}{l}\text { Latihan/Aktiviti dengan bahan } \\
\text { pembelajaran/permainan } \\
\text { Exercises/Activities with learning } \\
\text { materials/games }\end{array}$ & 1 & 2 & 3 & 4 & 5 & 6 & 7 & 8 & 9 & 10 \\
\hline 10. & $\begin{array}{l}\text { Penyelesaian masalah mudah } \\
\text { Simple problem solving. }\end{array}$ & 1 & 2 & 3 & 4 & 5 & 6 & 7 & 8 & 9 & 10 \\
\hline
\end{tabular}

Sekian, terima kasih.

That's all. Thank you 